\title{
History of the Rhesus factor and of neonatal jaundice
}

\author{
Vlad DIMA ${ }^{1}$, Andreea CALOMFIRESCU-AVRAMESCU ${ }^{1}$, Ana Maria Alexandra STANESCU², \\ Anca A. SIMIONESCU ${ }^{3,4}$ \\ ${ }^{1}$ Department of Neonatology, Filantropia Clinical Hospital, Bucharest, Romania \\ ${ }^{2}$ Department of Family Medicine, "Carol Davila" University of Medicine and Pharmacy, Bucharest, Romania \\ 3 "Carol Davila" University of Medicine and Pharmacy, Bucharest, Romania \\ ${ }^{4}$ Department of Obstetrics and Gynecology, Filantropia Clinical Hospital, Bucha-rest, Romania
}

\begin{abstract}
The history of icterus and neonatal jaundice has been recorded since the 17th century, when a French midwife first described jaundice (jaune) in twins. In 1940, Alexander Wiener and Karl Landsteiner discovered the Rh blood group, and they investigated the isoimmunization via antigen transfer across the placenta from the fetus. Other blood group systems implicated in isoimmunization were discovered between 1901 and 1965. Between 1940-1960, many studies have focused on the etiology of hemolytic disease of the newborn, on incompatibility in the Rh system, cholestasis, metabolic diseases, inhibitors of breast milk, and the association between prematurity and jaun-dice or extremely nuclear jaundice. It is the merit of $A W$ Liley, in 1963, who described the diagram of the same name based on the level of bilirubin in the amniotic fluid and who performed the first fetal transfusions for fetal anemia. Last decades, non-invasive methods of diagnosis and treatment were described.
\end{abstract}

Keywords: icterus, neonatal jaundice, kernicterus, history of medicine

\section{INTRODUCTION}

As the past is the preface of the future, knowing the history of clinical signs of diseases is of great importance for identifying obstacles to the diagnosis and treatment. Neonatology is a young specialty that appears for the treatments of newborns in 1960 [1], before this time, the care of the newborn was done by obstetricians and pediatricians. In 1881, the first doctor to use incubators for premature babies was Etienne Stéphane Tarnier, clinical professor of obstetrics in the University of Paris, the doyen of obstetrics in France a legendary scientific personality of the $19^{\text {th }}$ century [2].
Jaundice is the most common and one of the most serious problems that can occur in the newborn. Jaundice occurs when the liver cannot remove enough bilirubin from the plasma. When the problem is excessive bilirubin formation or limited uptake and conjugation, unconjugated bilirubin (indirect bilirubin) occurs in the blood. Bilirubin is potentially toxic to the central nervous system (CNS) and this is the most important cause for concern.

The aim of this article is to describe the way from the diagnosis of jaundice as a clinical sign, to jaundice pathophysiology and diagnostics. 


\section{THE COURSE OF HISTORY BEFORE 1900: JAUNDICE, BILIRUBIN, KERNICTERUS AND ISOIMMUNIZATION}

The history of identification of icterus and neonatal jaundice has been recorded since the $17^{\text {th }}$ century, when a French midwife first described jaundice (jaune) in twins. In 1609, Louise Bourgeois- the midwife of Queen Marie de Medici of France, daughter of the Grand Duke of Tuscany, first described jaundice in twins [3]. In 1609, Bourgeois assisted at a twin birth: the first twin dead at delivery, whereas the second developed rapidly worsening jaundice within a few hours and died three days after birth [4]. The term jaundice is from the French word "jaune" which means yellow.

Bilirubin, a potent antioxidant and an important agent involved in peroxide purification, normally protects the newborn who is deficient in antioxidants such as vitamin E, catalase and superoxide dismutase, compared to the toxicity given by oxygen in the first days of life. Extremely high and potentially dangerous levels of TSB are rare but can cause bilirubin encephalopathy, or kernicterus as it is also known, characterized by damage to the basal ganglia and brainstem $[5,6]$. Kernicterus caused by hyperbilirubinemia was common in neonates with $\mathrm{Rh}$ isoimmunization until the establishment of the exchange blood transfusion procedure for affected newborns and the administration of postpartum antiRh (D) immunoglobulin treatment to prevent sensitization of Rh-negative mothers.

\section{THE DISCOVERY OF BLOOD GROUPS}

In 1900, the immunologist Karl Landsteiner discovered the $A, B, 0$ blood groups and was awarded the
Nobel Prize in 1930 [7]. With his friend and colleague, Alexander Wiener, they discovered in 1940 the Rh blood group, and they investigated the isoimmunization via antigen transfer across the placenta from fetus. In 1940, Wiener et al. described atypical immune antiglobulin and report cases of stillbirth or newborns death in relation of anti-rhesus agglutinins [8]. Between 1901 and 1965, were discovered blood group with potential isoimmunization when fetomaternal incompatibility (Table 1) [7-25].

\section{HISTORY OF SCIENTIFIC PUBLICATIONS ABOUT ICTERUS, JAUNDICE AND MATERNO-FETAL INCOMPATIBILITIES}

The first documented scientific description of neonatal jaundice took place in the latter part of the 18th century. In 1785 Jean Baptiste Thimotee Baumes wrote the book "Treatment of jaundice or yellowing in newborns", for which he received a doctorate in medicine from the University from Paris. In his research, he describes the clinical evolution of 10 jaundiced newborns $[5,26,27]$.

Jaques Hervieux's 1847 work entitled "About jaundice in newborns" has long been considered a landmark. The author analyzed 45 newborns in his study, and he performed the autopsy on 44 cases of death by jaundice, but he also made clinical observations and many others that he included. His descriptions of anatomopathological findings were very detailed and systematic. He made some clarifications that we use today such as: physiological jaundice is common, occurs in $2 / 3$ of newborns and the evolution in the absence of complications is favorable, occurs in the first 2-4 days of life and disappears at 1-2 weeks of life with-

TABLE 1. Discovery of blood groups (Reproduced from Farud et al. [7])

\begin{tabular}{|l|c|c|}
\hline Blood Group & Year of first publication & Scientist \\
\hline ABO -System & 1901 & Landsteiner [9] \\
\hline M/N -System & 1927 & Landsteiner, Levine [10] \\
\hline P-System & 1927 & Landsteiner, Levine [11] \\
\hline Secretor /Non -(ss) & 1932 & Schiff, Sasaki [12] \\
\hline Factor Q & 1935 & Imamuras [13] \\
\hline Rhesus (Rh) & $1940 / 41$ & Candsteiner, Wiener [8,14] \\
\hline Lutheran (Lu) & 1945 & Mourant [16] \\
\hline Lewis (Le) & 1946 & Coombs, Mourant, Race [17] \\
\hline Kell (K) & 1946 & Walsh RJ, Montgomery et al. [18] \\
\hline Factor S/s & 1947 & Cutbush, Mollison [19] \\
\hline Duffy (FY) & 1950 & Race [20] \\
\hline Kidd (Jk) & 1951 & Levine [21] \\
\hline Diago (Di) & 1954 & Salmon et al. [22] \\
\hline Yt System & 1956 & Mann et al. [24] \\
\hline Auberger (AU) & 1961 & Swanson et al. [25] \\
\hline Xg & 1962 & \\
\hline Dombrock (Do) & 1965 & \\
\hline
\end{tabular}


out recurrence, also the distribution is cephalo-caudal, the yellow coloration includes the skin, mucous membranes and brain, and the treatment consists in the prevention of complications [28]. At the autopsies performed, Hervieux noticed that yellow coloration was present in all organs, but with great variability of color intensity. He mentioned that it was influenced by the degree of perfusion of the organ; the higher the vascularity, the more intensely colored the organ. He also identified the yellow coloration of the brain and documented the presence of jaundice in the cerebrospinal fluid [28].

Johannes Orth first published in 1875 images with the anatomopathological appearance of the brain in a newborn with severe jaundice, who died at two days of age. The autopsy report described the intense yellow coloration of the basal ganglia, the wall of the third ventricle, the hippocampus and the central parts of the cerebellum. He also indicated the association between jaundice and the presence of anemia for the first time and assumed the presence of a hematological cause [29].

While Orth's contribution was limited to this case presentation, in 1903, Christian Schmorl presented to the German Society of Anatomopathology the results of his autopsies of 120 jaundiced newborns [30]. He presented brain fragments stored in formaldehyde to support the different intensity of the coloration (Figure 1). The brains of all these newborns were jaundiced, but only in 6 cases was a staining phenomenon similar to that previously described by Orth. Schmorl coined the term kernicterus (basal ganglia jaundice) for this bilirubin impregnation model. When the article was published, the picture from the attached drawing was presented.

Schmorl also suggested that bilirubin avidity is different for neurons and glial cells, and in vitro studies in the 1990s by Danblot and colleagues support this hypothesis. He also raised the question of the neurotoxicity of bilirubin, being interested to know if, once in the cell, bilirubin causes apoptosis or if this process could be reversible. Other studies suggest that the spread of jaundice depends on bilirubin concentration, and the process can be stopped or slowed down with appropriate treatment [30]. Although the next century of scientific studies has added an enormous amount of information about the epidemiology and pathophysiology of neonatal jaundice and kernicterus, the contributions of Hervieux, Orth and Schmorl will undoubtedly continue to be seen as historical landmarks in our attempt to understand these phenomena.

Studies conducted in the years 1940-1960 focused on determining the etiology (hemolytic disease of the newborn, incompatibility in the Rh system, cholestasis, metabolic diseases, inhibitors of breast milk), risk factors (prematurity), complications (nuclear jaundice) and the treatment of jaundice, and the use of phototherapy for non-haemolytic jaundice and exchange blood transfusion in jaundice with significant hemolysis used since the 1980s [7].

The first cases of prenatal diagnosis of fetal hemolytic disease by ultrasonography or amniocentesis were published by Bevis in 1956 [31]. Nevertheless, unfortunately, he measured urobilinogen and non-haematin iron and did not reach any conclusions. It is the merit of AW Liley, in 1963, who described the diagram of the same name based on the level of bilirubin in the amniotic fluid and who performed the first fetal transfusions [32].

Regarding the treatment of neonatal jaundice, it is possible that the first evidence regarding phototherapy can be found carved in the temples of ancient Egypt: "From the time of the Pharaohs, most ancient civilizations and cultures have worshipped the sun or sun gods and appear to have made some connection between sunlight and health. The use of sunbaths by the ancient Romans and Greeks for maintaining general health and for therapeutic purposes is particularly well documented. Whether these ancient cultures ever made connections between specific disorders and sunlight exposure are difficult to know, but certainly, sunlight can be used successfully to treat many skin disorders. If nothing else, heliotherapy would have had an antirachitic and bactericidal action" [33].
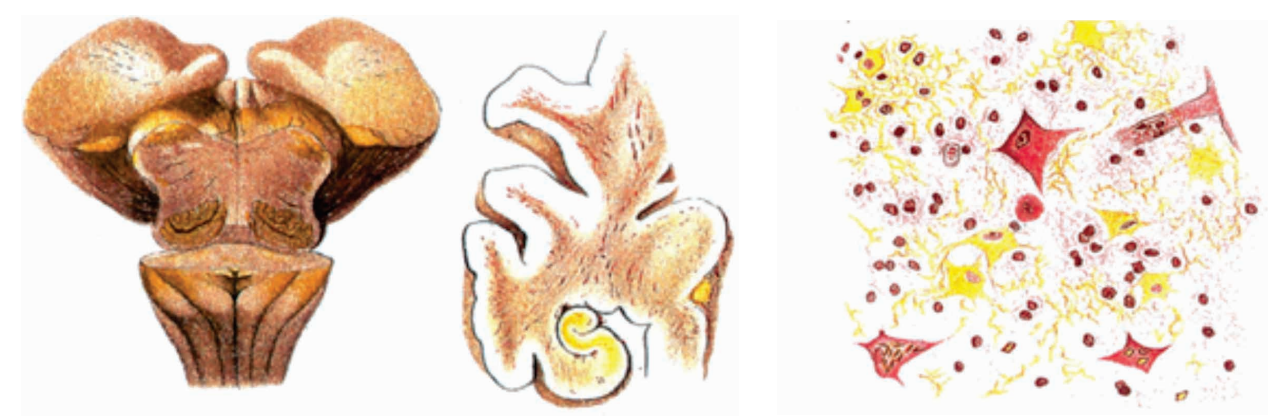

FIGURE 1. The colorful figure in Schmorl's 1904 publication, illustrates the findings that led him to the term nuclear jaundice (jaundice of the basal ganglia) (30) 


\section{CONCLUSIONS}

It took many years and many steps to get where we are today: the non-invasive diagnosis of jaundice and eradication of isoimmunization by maternal immuno- prophylaxis. Trying to find more markers for antenatal diagnosis may be the key to success.

Conflict of interest: none declared Financial support: none declared

\section{REFERENCES}

1. Philip AG. The evolution of neonatology. Pediatr Res. 2005;58(4):799-815.

2. Dunn PM. Stéphane Tarnier (1828-1897), the architect of perinatology in France. Arch Dis Child Fetal Neonatal Ed. 2002; 86(2):F137-139.

3. O'Dowd MJ, Philipp EE. The history of obstetrics \& gynecology. The Parthenon Publ. Group, 1994:87-92.

4. Bowman JM. Hemolytic disease of the newborn. Vox Sang. 1996; 70(Suppl 3):62-67.

5. Erlinger S, Arias IM, Dhumeaux D. Inherited disorders of bilirubin transport and conjugation: new insights into molecular mechanisms and consequences. Gastroenterology. 2014;146(7):1625-1638.

6. MacDonald M, Seshia M. Avery's Neonatology - Patophysiology and Management of the Newborn, 7th ed. Elsevier, 2015:107-123.

7. Farhud DD, Zarif Yeganeh M. A brief history of human blood groups. Iran J Public Health. 2013;42(1):1-6

8. Landsteiner K, Wiener AS. An agglutinable factor in human blood recognized by Immune sera for rhesus blood. Proc Soc Exp Biol. 1940;43:223.

9. Landsteiner K. Ueber Agglutinationsersche inungen normalen menschlichen Blutes. Klin Wschr. 1901;14:1132.

10. Landsteiner K, Levine P. A new agglutinable factor differentiating individual human bloods. Proc Soc Exp Biol. 1927;24:600.

11. Landsteiner K, Levine P. Further observations on individual differences of human blood. Proc Soc Exp Biol. 1927;24:941.
12. Schiff F, Sasaki H. Der Ausscheidungstypus, ein auf serologischem wege nachweisbares Mendelndes Merkmal. Klin Wschr. 1932;11:1426

13. Imamura $S$. On the new blood type $Q$. Hanzaigaku Zasshi. 1935;9:580.

14. Landsteiner K, Wiener AS. Studies on an agglutinogen $(\mathrm{Rh})$ in human blood reacting with anti-rhesus sera and with human iso-antibodies. J Exp Med. 1941;74:309.

15. Callender S, Race RR, Paykoc Z. Hypersensitivity to transfused blood. Brit Med J. 1945;II:83.

16. Mourant AE. A "new" human blood group antigen of frequent occurrence. Nature. 1946;17(158):237.

17. Coombs RRA, Mourant AE, Race RR. In-vivo isosensitization of red cell in babies with hemolytic disease. Lancet. 1946;1(6391):264-266.

18. Walsh RJ, Montgomery C. A new human isoagglutinin subdividing the MN blood group. Nature. 1947;160(4067):505.

19. Cutbush M, Mollison PL. The Duffy blood group system. Heredity. 1950;4(3):383-389.

20. Race RR, Sanger R, Allen FH, Diamond LK, Niedziela B. Inheritance of the human blood group antigen JKa. Nature. 1951; 168(4266):207-8.

21. Levine P, Koch EA, NcGee RT, Hill HG. Rare human isoagglutinins and their identification. Am J Clin Path. 1954;24(3):292-304.

22. Eaton BR, Morton JA, Pickles MM, et al. A new antibody anti-Yta, characterizing a blood group of high incidence. Br J Haemat. 1956;2(4):333-341.

23. Salmon C, Salmon D, Liberge G, Andre R, Tippett $P$, Sanger R. A new erythrocytic blood group antigen present in 80 per cent of subjects of the white race. Nouv Rev Fr Hematol. 1961 Sep-Oct;1:649-61.

24. Mann JD, Cahan A, Gelb A, et al. A sex-linked blood group. Lancet. 1962;1(7219):8-10.

25. Swanson J, Polesky HF, Tippett P, et al. A 'New' Blood Group Antigen, Doa. Nature. 1965;206:313.

26. Baumes JBT. Treatise on Icterus or Jaundice of Newborn Infants. 2nd ed. Paris: Méquignon, 1806.

27. Hansen TW. Pioneers in the scientific study of neonatal jaundice and kernicterus. Pediatrics. 2000;106(2):E15.

28. Hervieux JFE. On the Jaundice of Newborns. University of Paris; 1847. Doctoral thesis.

29. Orth J. Uber das Vorkommen von bilirubinkrystallen bei neugeborenen Kindern. Virchows Arch Pathol Anat. 1875;63:447-462.

30. Schmorl G. Zur Kenntnis des icterus neonatorum insbesondere der dabeiauttretenden gehirnveränderungen. Verh Dtsch Ges Pathol. 1904;6:109-115.

31. Bevis DCA. Blood pigments in haemolytic disease of the newborn. J Obstet Gynecol.1956;63:68-75.

32. Liley AW. Intrauterine transfusion of foetus in haemolytic disease. Br Med J. 1963; 2(5365):1107-1109.

33. McDonagh AF. Phototherapy: from ancient Egypt to the new millennium. J Perinatol. 2001;21 Suppl 1:S7-S12. 